\title{
Antioxidant and antimicrobial activity of Kielmeyera coriacea Mart. and Zucc
}

Francisco José Tôrres de Aquino ${ }^{1 *}$, Carla de Moura Martins ${ }^{1}$, Sérgio Antônio Lemos de Morais ${ }^{1}$, Luís Carlos Scallon Cunha ${ }^{1}$, Gabriella Roqueti Guimarães Aloise ${ }^{1}$, Roberto Chang ${ }^{1}$, Alberto de Oliveira ${ }^{1}$, Thais da Silva Moraes ${ }^{2}$, Wilson R. Cunha ${ }^{2}$ and Carlos Henrique G. Martins ${ }^{2}$

\footnotetext{
'Laboratório de Produtos Naturais e Cromatografia, Instituto de Química, Universidade Federal de Uberlândia, Av. João Naves de Ávila, 2121, CEP 38408-100. Uberlândia-MG, Brazil.

${ }^{2}$ Núcleo de Pesquisas em Ciências Exatas e Tecnológicas, Universidade de Franca, Av. Dr. Armando Salles Oliveira, 201, CEP 14404-600. Franca-SP, Brazil.
}

Accepted 19 September, 2013

\begin{abstract}
Kielmeyera coriaceae Mart. and Zucc. belongs to Clusiaceae family and is largely distributed in the cerrado Brazilian biome. In this study, phytochemical screening, the antioxidant and antimicrobial activities of aerial parts of the $K$. coriacea were evaluated. The extracts showed the presence of terpenoids, saponins, triterpenes, steroids, flavonoids, tannins and phenolic compounds. Ethanolic extract and partitions of plant parts of $K$. coriacea showed a very strong antioxidant activity, in particular, the inner bark of the plant. The ethanolic extract and the cyclohexane fraction of the inner bark showed high antimicrobial activity against oral pathogens with minimum inhibitory concentrations (MIC) between 3.1 and $100 \mu \mathrm{g} \mathrm{ml}^{-1}$. The cyclohexane fraction was the most active with CIMs of $6.2 \mu \mathrm{g}$ $\mathrm{ml}^{-1}$ for most of the tested bacteria, including Streptococcus mutans, the main etiological agent of dental caries. The ethanolic extract exhibited the highest antibacterial activity against Streptococcus mitis, with MIC value of $3.1 \mu \mathrm{g} \mathrm{ml}^{-1}$, a value lower than that found by the positive control. The antioxidant and antimicrobial activities could be due to the different phytochemical classes presented in the ethanolic extract and partitions studied. The antioxidant activity and the antimicrobial activity showed by the ethanolic extract and cyclohexene fraction of the inner bark were considered promising.
\end{abstract}

Key words: Kielmeyera coriacea, Clusiaceae, extracts phytochemical, antioxidant, antimicrobial activities.

\section{INTRODUCTION}

The Cerrado is the second largest biome found in Brazil, providing about 160,000 species of plants, animals and fungi (Brannstrom et al., 2008) and is recognized as the richest savanna in the world, housing 11,627 native plant species already cataloged (MMA, 2013), having 220 species with medicinal use. Among these species is the Kielmeyera coriacea Mart. and Zucc, largely distributed in the cerrado and whose aqueous extract is used to treat various tropical diseases such as malaria, schistosomiasis, leishmaniasis, bacterial and fungal infection (Ferri, 1969; Zagoto et al., 2006; Audi et al., 2002). Furthermore, the resin extracted from the bark of $K$. coriacea is used in folk medicine for treatment of dental pain (Pinto et al, 1993; Corrêa, 1952). The genus 
Kielmeyera belongs to the family Clusiaceae, the second richest genera in Brazil, with 46 species and two subspecies with large distribution (Bittrich, 2010). Dichloromethane extracts of $K$. coriacea leaves and stems are rich in xanthones, triterpenes and biphenileted compounds (Cortez et al., 2002; Cortez et al., 1998). Some compounds isolated from the dichloromethane extract of leaves exhibited antimicrobial activity (Cortez et al., 2002), antifungal activity (Cortez et al. 1998) and the mixture of $\delta$-tocotrienol, and dimers found in hexane extract of the root bark from K. coriacea presented, in vitro, action against strains of cancer (Mesquita et al., 2011). The effect on the central nervous system of the hydroalcoholic extract of leaves and steam of $K$. coriacea was evaluated exhibiting a substantial anxiolytic effect (Audi et al., 2002; Otobone et al., 2007). Studies on antimicrobial activity of extracts of other Kielmeyera species are known. The ethyl acetate and ethanolic extracts from Kielmeyera neglecta have shown activities against multidrug-resistant bacteria Enterococcus faecalis and Staphylococcus aureus (Adrioli et al., 2012). The dichloromethane extract of the stem of Kielmeyera cuspidata exhibited antibacterial activity for the microorganisms Micrococcus luteus, Bacillus subitilis, Staphylococcusaureus and Streptococcus mutans (Sobral et al., 2009).

To the best of our knowledge, there is no previous report on the antioxidant and antimicrobial activity against oral pathogens of extracts and partitions of the specie $K$. coriacea. So, the main objective of this work was evaluating these biological activities of the aerial parts of the K. coriacea.

\section{MATERIALS AND METHODS}

\section{Plant materials}

Aerial parts of the $K$. coriacea Mart. \& Zucc. were collected in Jardim Karaíba district, located in the city of Uberlândia, Minas Gerais state, Brazil (1894'08.27"S, 48²6'06.40"W), in April 2010. The plant material was identified properly by a specialist (Prof. Glein Monteiro de Araújo, Institute of Biology-UFU), and a voucher specimen (57181) of the plant was deposited in the herbarium of the Federal University of Uberlândia, Brazil.

\section{Preparation of extracts}

Aerial parts of $K$. coriacea were air-dried, cleaned, cut into small pieces, peeled, minced, and subsequently milled. $100 \mathrm{~g}$ of each powdered material (leaves, wood, inner bark, and outer bark) was weighed, homogenized and extracted with $500 \mathrm{ml}$ of ethanol $(95 \%$ purity) as solvent using Soxhlet apparatus, and subjected to continuous hot percolation for $6 \mathrm{~h}$ (Hargeman et al. 1998). Each crude extract was decanted, filtered under vacuum, and then concentrated by a rotary evaporator at $40^{\circ} \mathrm{C}$, to give a viscous dark mass. Each dried sample was weighed, yielding (\%) $20.47 \pm 0.6$ of leaves, $16.38 \pm 0.1$ of inner bark, $7.47 \pm 0.3$ of outer bark and $0.54 \pm 0.2$ of wood extract. They were transferred to amber flasks and stored at $-18 \pm 5^{\circ} \mathrm{C}$ for further analysis.

\section{Liquid-liquid partition of ethanol extracts}

A sample $(10 \mathrm{~g})$ of the crude ethanolic extract of each aerial plant parts was resuspended in $200 \mathrm{ml}$ of methanol/water (9:1). Liquidliquid partition was performed using a sequence of solvents (cyclohexane, dichloromethane, ethyl acetate and methanol). In total, $600 \mathrm{ml}$ of each of the solvents $(3 \times 200 \mathrm{ml})$ were used. The solutions of cyclohexane, dichloromethane, ethyl acetate and methanol with their extraction had their solvent evaporated under reduced pressure, at a temperature of $40^{\circ} \mathrm{C}$.

\section{Phytochemical screening}

The preliminary qualitative phytochemical tests of different extracts of $K$. coriacea were analyzed and the methods were described by Wagner and Bladt (1996). $1000 \mathrm{ppm}$ solution in methanol of each sample was used for the screening. The following phytoconstituents, namely, alkaloids, amino acids, terpenoids, saponins, triterpenes, steroids, flavonoids, tannins and phenolic compounds were screened. The samples were applied to the TLC plates and a positive result was given by the following tests:

1) Detection of alkaloids: the alkaloids appear as brown or orangebrown zones immediately spraying Dragendorff reagent.

2) Detection of amino acids: the amino acids appear as a red-violet color with ninhydrine.

3) Detection of terpenoids: immediately after spraying phosphomolybdic acid the constituents show uniform blue zones.

4) Detection of saponins: inspection under UV-365 nm light results in blue, violet and green fluorescent zones with Anisaldehydesulphuric acid reagent.

5) Detection of triterpenes and steroids: development of fluorescence under UV-365 $\mathrm{nm}$ light indicates the presence of sterols and triterpenes with Liebermann-Burchard reagent.

6) Detection of flavonoids: typical intense fluorescence in UV-365 $\mathrm{nm}$ as orange or yellow colors is produced immediately on spraying NP/PEG reagent.

7) Detection of tannins and phenolic compounds: the compounds can be identified by ferric chloride reagent with the formation of color patches Prussian blue.

\section{Antioxidant activity}

\section{Determination of total phenolic content}

The total phenolic content was determined using the modified FolinCiocalteau reagent method (Singleton et. al., 1965; Sousa et. al 2007) and gallic acid as standard. $12.5 \mathrm{mg}$ of the test sample were transferred quantitatively into a volumetric flask and the final volume $(50.0 \mathrm{ml})$ was completed with methanol. An aliquot of $0.5 \mathrm{ml}$ was transferred to a test tube. Then, $2.5 \mathrm{ml}$ of a solution of FolinCiocalteu reactive $\left(10 \% \mathbf{v ~ v}^{-1}\right)$ and $2.0 \mathrm{ml}$ of $\left(7.5 \% \mathbf{v} \mathbf{v}^{-1}\right) \mathrm{Na}_{2} \mathrm{CO}_{3}$ solution were added. This mixture was kept in a water bath at a temperature of $50^{\circ} \mathrm{C}$ for $5 \mathrm{~min}$. The absorbance was recorded at $760 \mathrm{~nm}$ in a UV-Vis U-300 (Hitachi, Kyoto, Japan) spectrophotometer. Gallic acid was used for the construction of a standard curve at various concentrations $(10,20,30,40,50,60,70$ and $80 \mathrm{\mu g} \mathrm{ml}^{-1}$ ). The total phenolic content was determined by interpoling the samples absorbance values against a calibration curve constructed from standards of gallic acid $(100$ to $1000 \mu \mathrm{g} \mathrm{ml}$ $\left.{ }^{1}\right)$. The results were expressed as $\mathrm{mg}$ of gallic acid equivalents (GAE) $\mathrm{g}^{-1}$ of dry extract (Table 2). The analyses were performed in triplicate. 


\section{Determination of total proanthocyanidins}

The total proanthocyanidin content was determined by the vanillin method with modifications (Godefroot et al., 1981). An aliquot of 2 $\mathrm{ml}$ from the solution prepared for the total phenolic content was transferred to a test tube. Then, $3 \mathrm{ml}$ of a freshly prepared solution of vanillin in sulphuric acid $\left(70 \% \vee v^{-1}\right)$ solution was added. The resulting solution $\left(5000 \mu \mathrm{g} \mathrm{ml}^{-1}\right)$ was kept in a water bath at a temperature of $50^{\circ} \mathrm{C}$, for $15 \mathrm{~min}$. The sample was cooled and the absorbance was recorded at $500 \mathrm{~nm}$ in a UV-Vis U-300 (Hitachi, Kyoto, Japan) spectrophotometer. The content of tannins was determined by interpolating the samples absorbance values against a standard curve constructed from standards of catechin (100 to $1000 \mathrm{~g} \mathrm{ml}^{-1}$ ). The standard curve was constructed under the same reaction conditions where the sample was replaced by catechin. The results were expressed as $\mathrm{mg}$ of catechin equivalents (CE) $\mathrm{g}^{-1}$ of dry extract (Table 2). The analyses were performed in triplicate.

\section{Quantitative analysis of antioxidant activity $\left(\mathrm{EC}_{50}\right)$}

The antioxidant activity was determined following the method described by Brand-Williams et al (1995). Stable free radical 2,2diphenyl-1-picrylhydrazyl (DPPH, $\geq 85 \%$; FLUCKA) was used for the construction of a standard curve (dilutions of $50,45,40,35,30$, $25,20,15,10,5$ and $1 \mathrm{\mu g} \mathrm{ml}^{-1}$ were used). The absorbance measurements were performed in triplicate with $1 \mathrm{~min}$ of intervals between each reading. For the preparation of aqueous solutions, ultra-purified water (Millipore Milli-Q system with resistivity $\geq 18 \mathrm{M} \Omega$ $\mathrm{cm})$ was used. The ethanolic extracts or partitions solutions $(500 \mu \mathrm{g}$ $\mathrm{ml}^{-1}$ ) of each plant part of $K$. coriacea and the positive control were diluted in methanol at concentrations of 250 to $25 \mathrm{\mu g} \mathrm{ml}^{-1}$ and then added to $3.9 \mathrm{ml}$ of freshly prepared DPPH solution (about $40 \mu \mathrm{g} \mathrm{ml}^{-}$ 1 in $\mathrm{MeOH}$ ). The absorbance was recorded at $515 \mathrm{~nm}$ for one hour, at intervals of 5 min between each reading. Methanol solution (250 $\mu \mathrm{g} \mathrm{ml}^{-1}$ ) of BHT (butylated-hydroxy-toluene, ALDRICH) was used as positive control. The $\mathrm{EC}_{50}$ (concentration of antioxidant required to reduce the initial concentration of free radical DPPH to $50 \%$ ) was calculated from a calibration curve by linear regression. This methodology for determining the $\mathrm{EC}_{50}$ using the computational resource is already properly established.

\section{Antimicrobial activity}

The antimicrobial activity of the crude extracts and fractions was determined by the broth microdilution through the minimal inhibitory concentration (MIC). The MIC was defined as the lowest concentration of the extract in which the microorganism did not demonstrate visible growth.

\section{Test microorganisms}

Four clinical oral bacteria species from "American Type Culture Collection" (ATCC) were used as test organisms in the screening: aerobic - Streptococcus sanguinis (ATCC 10556), S. mitis (ATCC 9456), and S. mutans (ATCC 25175); anaerobic - Actonomices naeslundii (ATCC 19039).

\section{Minimum inhibitory concentration (MIC): broth microdilution method}

The assays were carried out under Clinical and Laboratory Standards Institute procedures for aerobic microorganisms (CLSI,
2006) and for anaerobic microorganisms (CLSI, 2007). The MICs of the samples against the test bacterial strains were performed according to the broth microdilution method. The entire procedure was performed in a laminar flow hood, with all of the glassware, pipette tips, culture media and 96-well microplates sterilised (Porto et al., 2009; Carvalho et al., 2011). Samples were dissolved in $1 \mathrm{mg}$ $\mathrm{ml}^{-1}$ dimethyl sulphoxide (DMSO), followed by dilution in tryptic soy broth (Difco) for aerobic and Schaedler broth (Difco) supplemented with haemin $\left(5 \mu \mathrm{g} \mathrm{ml}^{-1}\right)$ and vitamin $\mathrm{K} 1\left(10 \mu \mathrm{g} \mathrm{ml}^{-1}\right)$ for anaerobic; concentrations ranged from 400 to $10 \mu \mathrm{g} \mathrm{ml}^{-1}$. The final DMSO content was $5 \%(\mathrm{v} / \mathrm{v})$, and this solution was used as a negative control. The inoculum was adjusted for each organism to yield a cell concentration of $5 \times 10^{5}$ colony forming units (CFU) $\mathrm{ml}^{-1}$. One inoculated well was included to enable control of the adequacy of the broth for organism growth. One non-inoculated well, free of antimicrobial agent, was also employed to ensure medium sterility. Chlorhexidine dihydrochloride (CHD) was used as a positive control. The microplates (96-wells) containing the aerobic microorganisms were sealed with plastic film and incubated at $37^{\circ} \mathrm{C}$ for $24 \mathrm{~h}$. The anaerobic microorganisms were incubated for 48 to $72 \mathrm{~h}$ in an anaerobic chamber (Don Whitley Scientific, Bradford, UK), in 5 to $10 \% \mathrm{H}_{2}, 10 \% \mathrm{CO}_{2}, 80$ to $85 \% \mathrm{~N}_{2}$ atmosphere at $37^{\circ} \mathrm{C}$. After that, resazurin $(30 \mu \mathrm{L})$ in an aqueous solution $\left(0.02 \% v^{-1}\right)$ was added to the microplates, to indicate microorganism viability for the determination of MIC. Chlorhexidine dihydrochloride (CHD) was used as a positive control and the concentrations ranged from $0.0115 \mu \mathrm{g} \mathrm{ml}^{-1}$ to $5.9 \mathrm{\mu g} \mathrm{ml}^{-1}$. The controls of sterility of TSB and Schaedler broths, control culture (inoculum), chlorhexidine sterility, sterility of the extracts and control DMSO were all performed and the analyses were performed in triplicate.

\section{Statistical analysis}

Determination of ethanolic extracts, total phenolics, proanthocyanidins and antioxidant activity were carried out in triplicate and the results were calculated as mean values (standard deviation). Significant differences were determined by the Tukey test (at a $5 \%$ level of significance) for comparison between the extracts and partitions and Holm-Sidak test for comparison between the samples and positive control (BHT), using SigmaPlot vertion 11.0. All data on the biological tests were submitted to treatment ANOVA with a significance level of $5 \%$ using the Tukey method in GraphPad Prism 5.

\section{RESULTS}

The ethanol extracts were concentrated under reduced pressure, yielding $20.5,16.4,14.9$, and $0.6 \mathrm{~g}$ for leaf, inner bark, outer bark and wood respectively. The liquidliquid partition of the ethanol extract of the wood was not performed because the mass of extract obtained was insufficient and beyond this fact, the wood consists mainly of lignin and holocellulose. The preliminary qualitative phytochemical tests of the different extracts of $K$. coriacea are shown in Table 1. The extracts showed the presence of terpenoids, saponins, triterpenes, steroids, flavonoids, tannins and phenolic compounds. Alkaloids and amino acids were absent in all extracts.

The results for total phenols, proanthocyanidins content and the effective concentration $\left(E_{50}\right)$ for aerial parts of K. Coriacea are presented in Table 2.

The antimicrobial activity of the ethanolic extracts and 
Table 1. Preliminary phytochemical screening (qualitative) of different extracts from K.coriacea.

\begin{tabular}{|c|c|c|c|c|c|c|c|}
\hline \multirow[b]{2}{*}{ Extracts } & \multicolumn{7}{|c|}{ Phytoconstituents } \\
\hline & Alkaloids & $\begin{array}{l}\text { Amino } \\
\text { acids }\end{array}$ & Terpenoids & Saponins & $\begin{array}{l}\text { Triterpenes } \\
\text { and steroids }\end{array}$ & Flavonoids & $\begin{array}{l}\text { Phenolic } \\
\text { compounds } \\
\text { and tannins }\end{array}$ \\
\hline EEL & - & - & + & + & + & + & + \\
\hline CPL & - & - & + & + & + & + & + \\
\hline DPL & - & - & + & + & + & + & + \\
\hline CPIB & - & - & + & + & + & + & + \\
\hline DPIB & - & - & + & + & + & + & + \\
\hline MWIB & - & - & + & + & + & + & + \\
\hline EEOB & - & - & + & + & + & + & + \\
\hline CPOB & - & - & + & + & + & + & + \\
\hline
\end{tabular}

+: Present; -: Absent; EEL: ethanolic extract of leaves; CPL: cyclohexane partition of leaves; DPL: dichloromethane partition of leaves; EEIB: ethanolic extract of inner bark; CPIB: cyclohexane partition of inner bark; DPIB: dichloromethane partition of inner bark; MWIB (9:1): methanol/water partition of inner bark; EEOB: ethanolic extract of outer bark; CPOB: cyclohexane partition of outer bark; DPOB: dichloromethane partition of outer bark; EEW: ethanolic extract of wood.

partitions was screened by the broth microdilution method (BMD) against important microorganisms belonging to strains of the collection ATCC, responsible for human oral diseases. The values of minimal inhibitory concentration (MICs) are presented in Table 3.

\section{DISCUSSION}

In general, ethanolic extract and partitions of plant parts of $K$. coriacea showed a very strong antioxidant activity. The inner bark was the plant part that presented the best results. The polar dichloromethane partition presented better results than the cyclohexane partition for total phenols and proanthocyanidns for all plant part analyzed. The outer shell showed the lowest amount of total phenols and proanthocyanidins in this solvent. The lower phenol content and proanthocyanidins found in cyclohexane partitions can be assigned to the nonpolarity of the solvent, since the compounds have phenolic hydroxyl and carbonyl groups, which have higher affinity for polar solvents.

The free radical DPPH assay provides basic information on the antiradical activity of extracts (Souza et. al., 2007). According to Table 2, the best results for the antioxidant activity (AA), expressed in terms of average effective concentration $\left(E_{50}\right)$ to scavenge the free radical DPPH, were those found in the inner bark part. Comparing the $\mathrm{EC}_{50}$ values with the well-know antioxidant standard BHT, the inner bark extract and partitions showed results similar, exception for the cyclohexane partition.

This part of $K$. Coriacea presented the highest total
Phenols and Proanthocyanidins contents in the ethanolic extract and all partitions showing a direct correlation between these bioactive compounds and $\mathrm{EC}_{50}$ (RiceEvans et al., 1997). Besides the antioxidant activity, phenolic compounds present physiologic property as antiinflammatory and antimicrobial too (Lang and Buchbauer, 2012).

Studies on antimicrobial activity of extracts of others Kielmeyera species are known. The ethyl acetate and ethanolic extracts from $K$. neglecta have shown activities against multidrug-resistant bacteria ( $E$. faecalis - ATCC 51299 and S. aureus - ATCC 43300), with $\mathrm{EC}_{50}$ of 12.5 $\mu \mathrm{g} \mathrm{ml} \mathrm{l}^{-1}$ (Adrioli et al., 2012). In this study, the values of minimal inhibitory concentration (MICs) found for aerobic and anaerobic bacteria ranged from 3.2 to 400 .

The MIC values determination against oral pathogens using the broth microdilution method has been proved to be useful in the screening of extracts with antimicrobial activity and should be considered as an important tool in researches involving natural products. The ethanolic extract and the cyclohexane fraction of the inner bark were both the most effective against the microorganisms studied. The MICs values for these extracts ranged from 3.1 to $100 \mathrm{~g} \mathrm{ml}^{-1}$. Extracts from plants species with MIC values below $100 \mathrm{\mu g} \mathrm{ml}^{-1}$ and isolated compounds with MICs below $10 \mathrm{\mu g} \mathrm{ml}^{-1}$ are considered promising potential antimicrobial agents (Rios and Recio, 2005). The cyclohexane fraction of the inner bark inhibited the growth of $S$. mutans, the main etiological agent of dental caries at concentrations below $10 \mu \mathrm{g} \mathrm{ml}^{-1}$.

The ethanolic extract was more effective against the major etiologic agent of dental caries, the aerobic oral 
Table 2. Total phenols, proanthocyanidins and EC-50 content in the extracts and partitions from leaves, inner bark (IB), out bark (OB) and wood of $K$. coriacea.

\begin{tabular}{|c|c|c|c|c|c|c|c|c|c|c|c|c|}
\hline \multirow[t]{2}{*}{ Sample } & \multicolumn{4}{|c|}{$\begin{array}{c}\text { Total phenols } \\
\text { ( } \mathrm{mg} \mathrm{GAE} \mathrm{g}^{-1} \text { of dry weight of the extract) }\end{array}$} & \multicolumn{4}{|c|}{$\begin{array}{c}\text { Proanthocyanidins } \\
\text { ( } \mathrm{mg} \mathrm{CE} \mathrm{g}^{-1} \text { of dry weight of the extract) }\end{array}$} & \multicolumn{4}{|c|}{$\mathrm{EC}_{50}\left(\mu \mathrm{g} \mathrm{ml}^{-1}\right)$} \\
\hline & Leave & IB & OB & Wood & Leave & IB & OB & Wood & Leave & IB & OB & Wood \\
\hline EE & $309.0 \pm 4.0^{c}$ & $346.0 \pm 2.0^{c}$ & $77.2 \pm 2.7^{\mathrm{b}}$ & $130.0 \pm 2.0$ & $109.0 \pm 1.0^{c}$ & $328.0 \pm 1.0^{c}$ & $19.9 \pm 0.3^{b}$ & $18.4 \pm 1.0$ & $10.6 \pm 0.7^{\mathrm{a}}$ & $5.9 \pm 0.1^{\mathrm{b \#}}$ & $55.2 \pm 1.7^{b}$ & $25.5 \pm 3.9$ \\
\hline $\mathrm{CP}$ & $57.5 \pm 1.0^{\mathrm{a}}$ & $82.3 \pm 0.6^{a}$ & $27.7 \pm 2.7^{\mathrm{a}}$ & - & $32.2 \pm 1.4^{\mathrm{a}}$ & $102.0 \pm 1.0^{\mathrm{a}}$ & $8.5 \pm 0.3^{\mathrm{a}}$ & - & $133.0 \pm 2.0^{\mathrm{b}}$ & $16.0 \pm 1.7^{c}$ & $70.1 \pm 0.4^{c}$ & - \\
\hline DP & $139.0 \pm 1.0^{b}$ & $241.0 \pm 1.0^{b}$ & $125.0 \pm 1.0^{c}$ & - & $52.0 \pm 2.2^{b}$ & $253.0 \pm 3.0^{b}$ & $28.1 \pm 1.4^{c}$ & - & $12.7 \pm 0.6^{\mathrm{a}}$ & $6.6 \pm 0.9^{\mathrm{b \#}}$ & $21.1 \pm 0.8^{\mathrm{a}}$ & - \\
\hline MW (9:1) & - & $372.0 \pm 1.0^{d}$ & - & - & - & $410.0 \pm 3.0^{d}$ & - & - & - & $4.3 \pm 0.3^{\mathrm{a}}$ & - & - \\
\hline $\mathrm{BHT}^{*}$ & \multicolumn{12}{|c|}{$6.5 \pm 0.20^{\#}$} \\
\hline
\end{tabular}

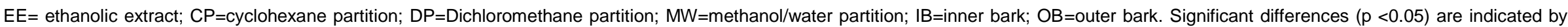
different letters in each column. Averages followed by the same letter or symbol in the column are not statistically different $(p>0.05) ;{ }^{*}$ Positive control.

Table 3. Inhibitory effect (MIC values) of the different extracts and partitions from $K$. coriacea.

\begin{tabular}{|c|c|c|c|c|}
\hline \multirow{3}{*}{ Sample } & \multicolumn{4}{|c|}{$\operatorname{MIC}\left(\mu \mathrm{g} \mathrm{ml}^{-1}\right)$} \\
\hline & \multicolumn{3}{|c|}{ Aerobic } & \multirow{2}{*}{$\begin{array}{c}\text { Anaerobic } \\
\text { A. naes/undii } \\
\text { ATCC } 19039 \\
\end{array}$} \\
\hline & $\begin{array}{c}\text { S. mitis } \\
\text { ATCC } 49456\end{array}$ & $\begin{array}{c}\text { S. mutans } \\
\text { ATCC } 25175\end{array}$ & $\begin{array}{l}\text { S. sanguinis } \\
\text { ATCC } 10556\end{array}$ & \\
\hline EEIB & 3.1 & 50 & 25 & 100 \\
\hline CPIB & 25 & 6.2 & 6.2 & 6.2 \\
\hline DPIB & 400 & 400 & $>400$ & $>400$ \\
\hline MWIB & 400 & $>400$ & $>400$ & 200 \\
\hline EEL & 400 & $>400$ & 400 & 200 \\
\hline $\mathrm{CPL}$ & $>400$ & $>400$ & 200 & $>400$ \\
\hline DPL & 200 & $>400$ & $>400$ & 400 \\
\hline EEOB & $>400$ & $>400$ & 400 & $>400$ \\
\hline CPOB & 400 & $>400$ & $>400$ & $>400$ \\
\hline DPOB & $>400$ & $>400$ & 400 & 400 \\
\hline Chlorhexidine dihydrochloride * & 3.688 & 3.688 & 1.844 & 1.844 \\
\hline
\end{tabular}


bacteria S. mitis (ATCC 49456) (MIC $3.1 \mu^{g \mathrm{ml}^{-1}}$ ), a MIC value lower than the positive control and is below to the isolated substances (Capel et al., 2011), to the same plant part. The cyclohexane fraction was more effective against the aerobic oral bacteria $S$. mutans (ATCC 25175), S. sanguinis (ATCC 10566) and against the anaerobic oral bacteria $A$. naesllundi (ATCC 19039) (all with MIC $6.2 \mu \mathrm{g} \mathrm{ml}^{-1}$ ).

The ethanolic extract, cyclohexane fraction and dichloromethane fraction of the leaves were more effective against the anaerobic bacteria $A$. naesllundi (ATCC 19039) and against the aerobic bacteria $S$. sanguinis (ATCC 10566) and S. mitis (ATCC 49456) respectively, with MIC $200 \mu \mathrm{g} \mathrm{ml}{ }^{-1}$. These results contribute to the potential use of these extracts against dental caries, supporting results in the folk medicine against dental pain (Neto et al., 2010). On the other hand, the ethanolic extract and partitions of outer bark does not presented the same promising results.

The results reached here can be considered very interesting for most microorganisms tested, below those considered promising for pure substances. In addition, these fractions presented MICs values lower than those found against the same bacteria for extracts and essential oils of others plant from Cerrado biome (Sobral et. al., 2009).

The antimicrobial activity is generally correlated, not only with a class of compounds, but with several of them, acting synergistically. Phenolic compounds present antibacterial activity (Pereira et. al., 2007). These and many others compounds are associated with the antimicrobial activity against dental pathogens (Lang and Buchbauer, 2012). The antibacterial activity of the $K$. coriacea extracts presented here may be related to phenolic compounds, flavonoids and tannins too, in synergism with others metabolic products screened in this work, as indicated by the literature (Wang et. al., 2004; Chang et. al., 2001).

\section{Conclusion}

The results of this study showed that the anti-oxidant activity and the antimicrobial activity presented by the ethanolic extract and cyclohexene fraction of the inner bark were considered very promising, for the prevention of dental caries and others oral pathologies. The second highest quantity of phenols and proanthocyanidins contents in this extract may explain these results.

\section{ACKNOWLEDGMENTS}

The authors thank Coordination for the Improvement of Higher Education Personnel (CAPES) for scholarship to C.M.M. and Federal University of Uberlandia for infrastructure support. The authors are also grateful to the Center for Research in Mathematical Sciences and
Technology/University of Franca (UNIFRAN) for the antimicrobial analyses and Prof. Glein Monteiro de Araújo (Institute of Biology-UFU) for plant identification.

\section{REFERENCES}

Adrioli JL, Sousa ZL, Oliveira FF, Conceição AO, Silva LAM, Rossi MH, Santos JS (2012). Biological activities of extracts from Chenopodium Ambrosioides Lineu and Kielmeyera Neglecta Saddi. Ann. Clin. Microb. Antimicrob. 11(20):1-7.

Audi EA, Otobone F, Martins JVC, Cortez D.A.G (2002). Preliminary evaluation of Kielmeyera coriacea leaves extract on the the central nervous system. Fitoterapia 73(6):517-519.

Brand-Williams W, Cuvelier ME, Berset C (1995). Use of a free radical method to evaluate antioxidant activity. Lebensm.-Wiss. u.-Technol., 28(1):25-30.

Brannstrom C, Jepson W, Fillipi MA, Redo D, Xu Ze, Ganesh S (2008). Land change in Brazilian Savana (Cerrado), 1986-2002: Comparative analysis and implications for land-use policy. Land use policy 25(4):579-595.

Capel CS, Souza ACD, Carvalho TC, Sousa JPB, Ambrósio SR, Martins CHG, Cunha WR, Galán RH, Furtado NAJC (2011). Biotransformation using Mucor rouxii for the production of oleanolic acid derivatives and their antimicrobial activity against oral pathogens. J. Ind. Microb. Biotec. 38(9):1493-1498.

Carvalho TC, Simão MR, Ambrósio SR, Furtado NA, Veneziani RC, Heleno VC, Da Costa FB, Gomes BP, Souza MG, Reis RB, Martins $\mathrm{CH}$ (2011). Antimicrobial Activity of Diterpenes from Viguiera arenaria against Endodontic Bacteria. Molecules 16(1):543-551.

Chang ST, Wu JH, Wanh SY, Kang PL, Yang NS, Shyur LF (2001). Antioxidant activity of extracts from Acacia confuse bark and heartwood. J. Agric. Food Chem. 49(7):3420-3424.

CLSI - CLINICAL AND LABORATORY STANDARDS INSTITUTE (2006). Methods for dilution antimicrobial susceptibility tests for bacteria that grow aerobically CLSI publication M7-A7.

CLSI - CLINICAL AND LABORATORY STANDARDS INSTITUTE (2007). Methods for dilution antimicrobial susceptibility.Testing of anaerobic bacteria. CLSI publication M11-A7.

Corrêa MP (1952). Dicionário das plantas úteis e exóticas cultivadas. Rio de Janeiro:Imprensa Oficial. P. 747.

Cortez DAG, Abreu Filho BA, Nakamura CV, Dias Filho BP, Marton A,

Hostettmann K (2002). Antibacterial activity of a biphenyl and xanthones from Kielmeyera coriacea. Pharm. Biol. 40:485-489.

Cortez DAG, Young AM, Marston A, Wolfender J.-L, Hostettmann K (1998). Xanthones, triterpenes and a biphenyl from Kielmeyera coriacea. Phytochemistry 47(7):1367-1374.

Ferri PH (1996). Química de produtos naturais: métodos gerais. In: DI STASI, L.C. Plantas medicinais: arte e ciência-um guia de estudos interdisciplinar. São Paulo:Unesp, pp. 129-156.

Godefroot M, Sandra P, Verzele M (1981). New method for quantitative essential oil analysis. J. Chromatogr. 203(9):325-335.

Hargeman AE (1988). Extraction of tannin from fresh and preserved leaves, J. Chem. Ecol. 14(2):453-61.

Lang G, Buchbauer $G$ (2012). A review on recent research results (2008-2010) on essential oils as antimicrobials and antifungals. A review. Flavor Fragr. J. 27(1):13-39.

Mesquita ML, Araújo RM, Bezerra DP, Braz-Filho R, Paula JE, Silveira ER, Pessoa C, Moraes MO, Lotufo LVC, Espindola LS (2011). Cytotoxicity of $\delta$-tocotrienols from Kielmeyera coriacea against câncer cell lines. Bioorg. Med. Chem. 19:623-630.

MMA-Ministério do Meio Ambiente. http://www.mma.gov.br/biomas/cerrado. Accessed in April, 2013.

Neto RMR, Santos JS, Silva MA, Koppe VC (2010). Potencialidades de uso de espécies em diferentes fisionomias do cerrado. Rev. Biol. Ciênc.Terra 10(2):113-126.

Otobone FJ, Sela VR, Obici S, Moreira LY, Cortez DAG, Audi EA (2007). Role of 5-HT1A receptors in antidepressant-like effect of dichloromethane fraction of Kielmeyera coriacea in rats subjected to the forced swim test. Indian J. Pharmacol. 39(2):75-79.

Pereira A, Ferreira I, Marcelino F, Valentao P, Andrade P, Seabra R, 
Estevinho L, Bento A, Pereira J (2007). Phenolic compounds and antimicrobial activity of olive (Olea europaea L. cv. Cobrancosa) leaves. Molecules 12(5):1153-1162.

Pinto JEBP, Arello EF (1993). Propagação in vitro de Kielmeiera coreacea: efeito das diversas concentrações combinadas de benzilaminopurina e ácido naftalenoacético na multiplicação de botos. Pesq. agropec. bras. 28(1):25-31.

Porto TS, Rangel R, Furtado NAJC (2009). Pimarane-type diterpenes: antimicrobial activity against oral pathogens. Molecules 14(1):191199.

Rice-Evans CA, Miller NJ, Paganga G (1997). Antioxidant properties of phenolic compounds. Trends Plant Sci. 2(4):152-159.

Ríos JL, Recio MC (2005). Medicinal plants and antimicrobial activity. J. Ethnopharmacol. 100(1-2):80-84.

Singleton VL, Rossi JA (1965). Colorimetry of total phenolics with phosphomolybdic-phosphotungstic acid reagents. Am. J. Enol. Vitic. 16:144-158.

Sobral IS, Souza-Neta LC, Costa, GAN, Guedes, MLS, Martins, D, Cruz FG (2009). Xanthones, triterpenes and antibacterial activity of dichloromethane extract of Kielmeyera cuspidata Saddi, Clusiaceae. Rev. Bras. Farmacogn. 19(3):686-689.
Sousa CMM, Silva HR, Vieira Junior GM, Ayres CC, Costa LS, Araújo DS, Calvacante LCD, Barros EDS, Araújo PBM, Brandão MS, Chaves MH (2007). Total phenolics and antioxidant activity of five medicinal plants. Quim. Nova, 30(2):351-355.

Wagner H, Bladt S (1996). Plant drug analysis: A thin layer chromatography atlas, Springer, Berlin, pp. 383-384.

Wang SY, Wu JH, Cheng SS, Lo CP, Chang HN, Shyur LF, Chang ST (2001). Antioxidant activity of extracts from Calocedrus macrolepis var. formosana leaf, bark and heartwood. J. Wood Sci., 50(5):422426

Zagoto JN, Bracht A, Pagadigorrie CLS, Ishi-Iwamoto EL, Cortez DAG, Yamamoto NS (2006). Effects of the Kielmeyera coriacea extract on energy methabolism in rat liver. J. Ethnopharmacol. 105(1-2):47-54. 